Amanda A. Chalupa*,

Division of Social and Cultural Psychiatry, McGill University, Canada Hye-Jie Jung ${ }^{* *}$, McGill University, Canada, Cécile Rousseau ${ }^{* * *}$, Division of Social and Cultural Psychiatry, McGill University, Canada

https://orcid.org/0000-0002-8294-8844

\title{
Posttraumatic Growth Following WWII: Polish people who were child refugees in New Zealand tell their story
}

\begin{abstract}
Posttraumatic growth (PTG) denotes positive changes that arise due to one's struggle with traumatic experiences. Despite growing interest in this field since the 1980s, PTG among individuals who have experienced trauma in childhood has been relatively understudied, and the process by which it occurs requires further examination. The narratives of 51 elderly Polish people who narrated their WWII experiences, deportation to Soviet labour camps, and migration to New Zealand as refugee children were analyzed by thematic content analysis. PTG was
\end{abstract}

\footnotetext{
Amanda A. Chalupa is a Ph.D. Candidate in Social and Cultural Psychiatry at McGill University in Montreal, Canada. Her research focuses on how people rebuild their lives following war, migration, and trauma, various memory processes, knowledge communication, and the role of the researcher in their own work. She is associate producer of the documentary film "Memory Is Our Homeland", which tells the story of Polish refugees in Africa during the Second World War and the odyssey that brought them there, while exploring themes related to her research. Her work brings together diverse disciplines and interest groups to improve how we collaborate between academia, research, entrepreneurship, business, government, non-profits, arts/culture and grassroots initiatives.

** Hye-Jin Jung earned her Bachelor of Arts in Psychology at McGill University in 2014. She is currently working as a Human Resources specialist, furthering her knowledge in understanding and motivating people.

Dr. Cécile Rousseau, MD is professor of the Division of Social and Cultural Psychiatry at McGill University. She has worked extensively with immigrant and refugee communities, developing specific school-based interventions and leading policy-oriented research. Presently, her research focuses on intervention and prevention programs to address violent radicalization.
} 
identified using the 5 factors of the Posttraumatic Growth Inventory: Relating to Others, New Possibilities, Personal Strength, Spiritual Change, and Appreciation of Life. The most commonly mentioned PTG dimension overall and among women was Changes in Interpersonal Relationships, a dimension that reflects a change that includes feeling closer to others, improvements in getting along with others, and a better understanding of others. Men reported instances of Changes in Perception of Self more frequently than women, though further analysis would be required to confirm significant gender differences. These results reveal that the experience of childhood trauma and migration may be affected by a country's welcome practices towards refugees, and that these experiences can influence personal transformations that occur across the lifespan.

Key words: Posttraumatic growth, narrative analysis, resilience, refugees, migration, Poland, New Zealand, personal transformation, Second World War, gerotranscendence, war trauma, Siberia, labour camp.

\section{Introduction $^{1}$}

Posttraumatic Growth (PTG) is a term that describes how one's struggles with traumatic events can act as catalysts for positive growth. It reflects changes in the dimensions of Interpersonal Relationships, Perception of Self, and Philosophy of Life ${ }^{2}$. Although there has been an increasing interest in examining PTG, most attention has been given to subjects who experienced trauma as adults. There are therefore relatively few studies examining PTG following a traumatic childhood experience as reported later in life ${ }^{3}$. To the best of our

1 This research was completed with the financial support of grants from the Social Sciences and Humanities Research Council of Canada (SSHRC) and the Fonds de recherche du Québec Société et culture (FRQSC)

2 L. G. Calhoun, and R. G. Tedeschi, Posttraumatic growth: Future directions, [in] Posttraumatic growth: Positive changes in the aftermath of crisis, Eds. R. G. Tedeschi, C. L. Park, and L. G. Calhoun, Mahwah, NJ: Lawrence Erlbaum Associates, 1998, pp. 215-238.

3 C. H. Cryder, R. P. Kilmer, R. G. Tedeschi, and L. G. Calhoun, An exploratory study of posttraumatic growth in children following a natural disaster, "American Journal of Orthopsychiatry", 76 (1): 2006, pp. 65-69. 
knowledge, this is the first study to examine - with the PTG framework - personal transformation associated with childhood trauma in the narratives of elderly Polish survivors of war and migration-related trauma as child refugees.

The purpose of this study is to offer insight into the personal transformation identified in the narratives of elderly Polish people who lived through WWII and were exiled to Soviet labour camps as children. The 21-item Posttraumatic Growth Inventory (PTGI) ${ }^{4}$ was applied in a thematic content analysis form to examine the individual narratives presented in the text "New Zealand's First Refugees: Pahiatua's Polish Children" 5 . These testimonials were written by elderly individuals who had been deported to Soviet labour camps as children and who were eventually resettled in New Zealand. Research questions relate to the different personal transformations that coincide with factors of posttraumatic growth identified in these narratives, as well as the conditions that may have encouraged posttraumatic growth. These research questions are addressed through the analysis of individual narratives that relate to the trauma experience, migration journey, and resettlement experience in New Zealand.

This paper begins with an overview of the historical context and experience of this group of children as they moved from Poland to New Zealand. Next, literature is presented regarding the long-term consequences of childhood trauma, and on research related to PTG and personal transformation. The research methods and theoretical framework are then outlined in greater detail. Results are presented by PTG dimension with notes on the specific context. The discussion focuses on what these results may reveal about this experience of childhood trauma, migration, and a country's welcome practices towards refugees, as well as how memories may transform over time. For the purpose of this paper, the experience of childhood trauma is related to the deportation experience and the repercussions of the deportation. The following section provides the historical context and details regarding the traumatic experience, migration journey, and resettlement context, in order to help situate the reader and ground the rationale for this particular study.

4 R. G. Tedeschi and L. G. Calhoun, The posttraumatic growth inventory: Measuring the positive legacy of trauma, "Journal of Traumatic Stress", 9 (3): 1996, pp. 455-471.

5 S. Manterys and S. Zawada, Eds., New Zealand's First Refugees: Pahiatua's Polish Children, Wellington: Polish Children's Reunion Committee, 2004. 


\section{Historical context: From Poland to New Zealand (1939-1950)}

In September 1939, both Nazi Germany and the Soviet Union invaded Poland, which the two totalitarian states subsequently occupied. Within the first two years of WWII, the Soviets deported anywhere between several hundred thousand and 1.5 million Polish citizens by cattle car trains from eastern Poland to Soviet labour camps and resettlement areas in "Siberia". This is a term that refers to both the geographical region and the vast labour camp, internment camp, and gulag system spread across the Soviet Union. Some estimates state that up to 380,000 children were deported, mostly at gunpoint from their homes, alone or with their families. Life in the camps varied by location, but overall living conditions were poor, with very little food and much hard physical labour. Children were often exposed to traumas such as witnessing death, experiencing forced exile, extreme hunger, forced labour, separation from family, freezing weather, and inadequate living conditions. Some children were sent to classrooms that were organized by the Soviets, which encouraged assimilation into Soviet society and thinking, with direct attacks on their Polish identities and culture. In 1941, the exiled Poles were liberated due to an Amnesty that was agreed upon among the Allies; a response to Operation Barbarossa and the Nazi turn against the Soviets that broke their previous Non-Aggression Pact (also known as the Molotov-Ribbentrop Pact). Given that Poland was part of the Allies, the Polish citizens in Siberia were allowed to make their way south to Iran, where transit camps existed and the Second Polish Corps was being formed under General Władysław Anders. Initially, only individuals and families that were army-affiliated were allowed to do so, but soon enough non-military affiliated people also began to make their way to Iran. In part as a response to the influx of children arriving in Iran, refugee camps were established around the world by the Polish Government-in-Exile based in London to care for these children, as well as for people who could not join the army and who could not return to war-torn Poland. At the end of WWII, Poland was under the Soviet sphere of influence, which complicated and largely deterred the possibility of returning to a Poland that had become largely controlled by the very forces that had led to their initial violent deportation. Furthermore, the borders of Poland had shifted west after WWII, and much of the land from which these Polish citizens had been deported had become a part of what is now Belarus and Ukraine. 
The children who arrived in New Zealand had a somewhat unique end to their migration journey. In 1944, the government of New Zealand accepted Polish children who had lost at least one parent during or following time in Soviet labour camps.

When on 9 June 1943 the US transport ship Hermitage, carrying a group of 706 Polish refugees from Iran to Mexico, anchored for a short time at Wellington, the wife of the Polish Consul, Countess Maria Wodzicka, visited them and conceived an idea of bringing some of the other Polish orphans from Iran to New Zealand. She shared her idea with Prime Minister Peter Fraser's wife, and eventually that idea became a reality when Mr Fraser and his government offered hospitality to 732 Polish children and 102 staff who were to accompany them ${ }^{6}$.

Invited as New Zealand's first refugees, these children were accepted and settled in the Polish Children's Camp in Pahiatua, a rural town 160km North East of Wellington. They were accompanied by adults who had travelled with them from Iran and had been similarly deported to Siberia. Some of these adults provided teaching and care, with many also serving as administrative personnel. Three schools rapidly established themselves at Pahiatua: a nursery and two gender-separated primary schools. Most of the children who were sent to New Zealand settled across the country once the camp closed in 1949. The children then went to local schools or took on work and trade apprenticeships. The New Zealand government and the Polish caregivers were responsible for the children's well-being, providing basic necessities, such as food, clothing, and education. Most of these children eventually became permanent citizens of New Zealand $d^{7,8,9,10,11}$.

6 Ibid., p. 24.

7 N. Davies, Trail of Hope: The Anders Army, an Odyssey Across Three Continents, Oxford: Osprey Publishing, 2015.

8 K. Jolluck, Exile and Identity: Polish Women in the Soviet Union during World War II, Pittsburg: University of Pittsburg Press, 2002.

9 L. Krolikowski, Stolen Childhood: A Saga of Polish War Children, Buffalo: Author's Choice Press, 2001.

10 S. Manterys and S. Zawada, op. cit.

11 M. Antosiewicz and K. Kubalska-Sulkiewicz, Polska Szkoła Na Tułaczych Szlakach; Polish Schooling in War-time Exile, Warsaw: FAFT, 2004. 
To illustrate how this journey may have played out in an individual child's life, we include here two case vignettes from the text "New Zealand's First Refugees: Pahiatua's Polish Children". Regina writes that:

When I was six, my mother died after the birth of our baby sister [...]. It was a very cold winter in 1940 and the country was at war. I remember how we cried all the time and missed our mother. Then on 10 February, only eight days after her funeral, the Soviet militia burst into our farmhouse at 2am, searched my father for weapons, and ordered him to pack his children and take whatever clothes and food we could take with us.

We were taken in that severe winter night to the nearest railway station, which was close to the Russian border. There we were loaded - shoved and pushed into cattle cars and taken north to Siberia. There were thousands of people on this train, one of the many from eastern Poland, in this first ruthless deportation of Polish citizens from their country.

Women tried desperately to help crying children and our baby sister was fed by other breastfeeding mothers or given boiled water, which was shared when guards allowed us to collect it at various stops on the journey. But the baby died soon after we arrived in the remote mountain place past the Ural Mountains. Many died on this journey. [...]

I remember that our father worked, like all other men and young people, in the mine. My sister [...], then 14, worked unloading the trolleys of copper ore on the surface. If people didn't work, they were not given bread rations either for themselves or their families. My eldest sister [...] was a housekeeper. [...], 12, was a nanny in a Russian family and the two youngest, myself and my brother [...], had to go to a Russian school. [...]

I remember our train journey from Wellington to the Polish Children's Camp in Pahiatua. [...] We saw beautiful colourful houses on hills, so different to those in Iran. And in Pahiatua we had a great reception, with the army band playing and photos taken with smiling, friendly people. Happiness was everywhere and we felt very welcome. [...] At the camp, we were divided into classes and housed in 
army barracks, with a bed and a chest of drawers, each nicely made up. Young New Zealand girls and boys tried to teach us tap dancing and took us to visit their homes or to the pictures [cinema] in Pahiatua ${ }^{12}$.

Antoni writes that:

My earliest memories go back to 1939, the year World War II broke out. As a fouryear-old, I vaguely remember that my father was arrested, and we were eventually deported to the Semipalatinsk region of Kazakhstan in the Soviet Union. From there, we were eventually evacuated to Iran.

Unfortunately, our salvation came too late and my mother died in Pahlevi, Iran, just a week after we were evacuated there. The terrible time and other hardships of our enslavement took their toll. I have always remembered my mum repeating to me over and over to never forget my name, date of birth, and that I was Polish and Catholic. Shortly after her death, I was taken to a Polish orphanage at Polish Civilians' Camp No 5 in Tehran to join hundreds of other orphans. Suddenly being alone among all these orphans was a very difficult time for me. Mum gave me a small photo of herself and I often looked at it so I would not forget what she looked like. I have kept that photo to this day.

Providence was good to me and, as it happened, I, together with a group of 732 children, was selected to go to New Zealand in 1944 for the remainder of the war. After that journey to New Zealand, we settled down to a stable and what seemed like a carefree life at the Polish Children's Camp in Pahiatua. Shortly after, my sister [...] found me through the Red Cross.

Everyone fell in love with Wellington and the beautiful countryside in Wairarapa. The camp became a home away from home - "Our little Poland". Even the camp's streets had Polish names. Most of us look back on those years at the camp as some of the happiest in our lives ${ }^{13}$.

12 S. Manterys and S. Zawada, op. cit., pp. 185-186.

13 Ibid., pp. 168-169. 
Among the most striking elements of this migration story is how the welcome and initial life in New Zealand is often recalled positively. As the children disembarked at the Wellington wharf, they were greeted by cheering crowds, heartfelt speeches, a band, cameras and a film crew. Ryszard recalls that: "As we were shepherded to the train for the journey to Pahiatua, someone in the crowd handed be some candy. [...] As I recall, it was shaped in the form of small biscuits in different colours and tasted heavenly. This was my first taste of candy"14. For many, this hospitality lasted beyond the children's initial arrival. Pahiatua may have helped to provide an environment for healing and a social context to facilitate PTG. Ryszard continues that for "a young kid [it] was a paradise. We made our own toys and our surroundings were a magic land - a river, native bush and the surrounding farms which we raided for turnips"15. Many narratives suggest that the children were well cared for and were invited to perform their traditional dances, plays, and songs.

These recollections and those of others reflect the collective memory and shared history of those who experienced this journey and time in Pahiatua. Today, the Poles of New Zealand have a strong community and an overall positive connection to their refugee welcome. The narratives that reflect these beginnings offer a contrast to much of what is presented regarding modern welcome practices for refugees, though examples of similarly welcoming arrivals do exist. Given this difference from the norm in terms of welcome practices, we reflect: could the overall positive collective narrative reveal an avoidance of presenting personal hurt, or rather does it converge with a narrative of personal transformation?

\section{Lasting effects of childhood trauma}

Childhood traumas related to war can have long-lasting effects. For example, according to Robinson and colleagues ${ }^{16}$, some child survivors of the Holocaust continued to experience symptoms of survivor syndrome even 50 years after

14 Ibid, p. 97.

15 Ibid.

16 S. Robinson, M. Rapaport-Bar-Sever, and J. Rapaport, The present state of people who survived the Holocaust as children, "Acta Psychiatrica Scandinavica", 89 (4): 1994, pp. 242-245. 
the end of persecution. Despite numerous findings of negative outcomes in the aftermath of trauma, there is increasing evidence that the role of resilience has been overlooked ${ }^{17}$. Some elements that helped traumatized individuals, such as war refugees ${ }^{18}$, overcome adverse circumstances include the ability to seek and obtain positive social support, spiritual or religious affiliation, high self-regard, optimism, and competence ${ }^{19}$. Individuals who experience trauma as children may indeed become well-functioning adults. In a study by Sigal and Weinfeld ${ }^{20}$ which involved a group of Holocaust survivors 40 years after the trauma, those who were children in 1945 expressed less paranoia and depressive/masochistic symptoms than those who were adolescents or young adults at the time. Possible explanations for this difference among the child survivors are their caregivers, psychodynamics, endowment, and social and cognitive development following the war. A PTG framework offers particular attention to the possibility that people may experience growth, and even thrive, despite adverse situations. The role of the surrounding environment in this process remains to be determined and better understood. Important activities and priorities for refugee children in host countries are to reunite them with family or other caregivers, to provide a school setting, and to promote community-building activities ${ }^{21}$.

\section{Personal transformation: PTG and Gerotranscendence}

There is a general notion that the more traumatic an event, the more impaired an individual will become, and thus, the more difficulty they will have

17 M. Giberovitch, Recovering from Genocidal Trauma: An Information and Practice Guide for Working with Holocaust Survivors, Toronto: University of Toronto Press, 2014.

18 N. Peddle, Assessing trauma impact, recovery, and resiliency in refugees of war, "Journal of Aggression, Maltreatment \& Trauma", 14 (1-2): 2007, pp. 185-204.

19 A. S. Masten, K. M. Best, and N. Garmezy, Resilience and development: Contributions from the study of children who overcome adversity, "Development and Psychopathology", 2 (4): 1990, pp. 425-444.

20 J. J. Sigal and M. Weinfeld, Do children cope better than adults with potentially traumatic stress? A 40-year follow-up of Holocaust survivors, "Psychiatry", 64 (1): 2001, pp. 69-80.

21 A. Ager, L. Stark, B. Akesson, N. Boothby, Defining Best Practice in Care and Protection of Children in Crisis-Affected Settings: A Delphi Study, "Child Development", 81 (4): 2010, pp. 12711286. 
recuperating 22 . However, contradicting these observations, Calhoun and Tedeschi $^{23}$ note that as many as $70 \%$ of the people that they surveyed reported positive aspects of having gone through traumatic experiences, including changes in interpersonal relationships, perception of self, and philosophy of life. For instance, although Holocaust survivors may be viewed as severely traumatized, some studies have shown that they reported more favourable resolutions than unfavourable ones, and had "very positive views about their lives, accomplishments, and goals" 24 . In the psychotherapeutic approach of logotherapy, Frank $1^{25}$ has suggested that the attitude taken towards suffering that is unavoidable promotes the process of meaning-making. Similar to how Lazarus and Folkman ${ }^{26}$ emphasize the importance of one's cognitive appraisal over stressors, further study is necessary to examine how situations and life experiences can be appraised under specific conditions, and how adjustment and development can be affected over time.

Given that this study specifically analyzed the reflections of elderly individuals who experienced childhood trauma, it is relevant to review the concept of gerotranscendence as it relates to PTG. Whereas PTG is a model of positive changes that follow traumatic events, gerotranscendence theory describes positive changes that relate to the aging process. The three dimensions of PTG/ gerotranscendence, respectively, are: Interpersonal Relationships/Social Relationships, Perception of Self/Self, and Philosophy of Life/Worldview27, 28, 29.

22 S. Robinson, M. Rapaport-Bar-Sever, and J. Rapaport, op. cit., pp. 242-245.

23 L. G. Calhoun, and R. G. Tedeschi, Facilitating Posttraumatic Growth: A Clinician's Guide, London: Erlbaum, 1999.

24 P. Suedfeld, E. Soriano, D. L. McMurtry, H. Paterson, T. L. Weiszbeck, and R. Krell, Erikson's "components of a healthy personality" among Holocaust survivors immediately and 40 years after the war, "International Journal of Aging and Human Development", 60 (3): 2005, p. 240.

25 V. E. Frankl, Man's Search for Meaning (revised and updated), New York: Square Press/ Pocket Books, 1984.

26 R. S. Lazarus and S. Folkman, Transactional theory and research on emotions and coping, "European Journal of Personality", 1 (3): 1987, pp. 141-169.

27 L. G. Calhoun, and R. G. Tedeschi, Posttraumatic growth: Future directions, pp. 215-238.

28 R. G. Tedeschi and L. G. Calhoun, Posttraumatic Growth: Conceptual Foundations and Empirical Evidence, "Psychological Inquiry", 15 (1): 2004, pp. 1-18.

29 L. Tornstam, Gerotranscendence: A Developmental Theory of Positive Aging, Springer Publishing Company 2005. 
While these two paths to personal transformation overlap in some ways (such as common areas of growth, salutogenic and phenomenological bases, social contexts in facilitating growth, and this growth's connection to well-being, wisdom, and life satisfaction), the key difference is what triggers growth. Although the trauma, crisis, and aging literature have separately addressed personal transformation and psychosocial well-being, their similarities are beginning to be empirically analyzed ${ }^{30}$, thereby increasing our understanding of how personal transformation occurs across the lifespan. Such transformations are defined by Tedeschi and Calhoun as the changes that occur in mental structures and worldviews.

\section{Research questions}

Although the idea that negative experiences can stimulate positive changes has not been unfamiliar throughout history, scholars shifted their interests to measuring positive outcomes of traumatic events in the 1980s and 90s, with the development of scales that measured positive growth. A developmental perspective of PTG had been lacking in the literature ${ }^{31}$. Calls have been made for more consideration to be given to long-term outcomes ${ }^{32}$, while those who experienced trauma during childhood have been relatively under-examined ${ }^{33}$. Moreover, the available literature on these topics has heavily focused on examining PTSD, leading to a shortage of studies that examine the processes by which individuals experience growth ${ }^{34}$. This study addresses the following research questions: (1) What are the different personal transformations that coincide with factors of posttraumatic growth in the collective narratives of elderly

30 T. Weiss, Personal transformation: Posttraumatic growth and gerotranscendence, "Journal of Humanistic Psychology”, 54 (2): 2014, pp. 203-226.

31 C. Aldwin and M. Levenson, Posttraumatic growth: A developmental perspective, "Psychological Inquiry", 15: 2004, pp. 19-22.

32 M. Fazel, R. V. Reed, C. Panter-Brick, and A. Stein, Mental health of displaced and refugee children resettled in high-income countries: Risk and protective factors, "Lancet", 379: 2012, pp. 266-282.

33 C. H. Cryder, R. P. Kilmer, R. G. Tedeschi, and L. G. Calhoun, op. cit., pp. 65-69.

34 R. G. Tedeschi and L. G. Calhoun, op. cit., pp. 1-18. 
Polish-New Zealanders who experienced war and migration-related trauma during WWII? and (2) What were some of the conditions that appear to have encouraged posttraumatic growth? The objective of these research questions is to use historical material to document reactions to stress and to analyze what factors might have helped children experience positive growth. Individual narratives written to showcase a collective experience serve as a unique window into understanding these understudied phenomena.

\section{Method}

\section{Theoretical framework}

The PTG model conceptualizes how positive changes follow trauma and stressful events through three dimensions of change: Interpersonal Relationships, Perception of Self, and Philosophy of Life ${ }^{35}$. The salutogenic orientation allows the human condition to be better understood by shifting a deficitbased approach that focuses on trauma resulting in pathology and misery to a strengths-based approach that understands trauma as an opportunity potential growth and demonstrations of human strength ${ }^{36},{ }^{37}$. With this in mind, a phenomenological lens gives precedence to the individual voice and subjective experience of trauma. This lens is integral to the development of the PTG model by clinicians Tedeschi and Calhoun, emerging from the reports of individuals who experienced traumatic events ${ }^{38}$. As an ecological model, it identifies events, individuals, and social contexts as the functions of positively coping with trauma. Growth may be triggered if at least one of these three characteristics is considered as a challenge to basic beliefs and goals, serving as a "turning point" with a "before" and an "after" phase identified in the life narrative. The resulting cognitive-emotional process facilitates the reassessment and/or reconstruction of goals, beliefs, life narratives, and basic

35 L. G. Calhoun, and R. G. Tedeschi, Posttraumatic growth: Future directions, pp. 215-238.

36 A. Antonovsky, Health, Stress, and Coping, Jossey-Bass, San Francisco 1979.

37 T. Weiss, op. cit., pp. 203-226.

38 Ibid., pp. 203-226. 
schemas. PTG is associated with the events or contexts that provide positive models of change and support ${ }^{39}$.

\section{Overall design}

Writers of narratives provided rich, detailed accounts of significant life experiences. Given the uniqueness of the particular migration experience, analysis of narratives allowed for common, recurrent PTG factors to be identified, as well as for the analysis of contexts in which these items emerged. The book "New Zealand's First Refugees: Pahiatua's Polish Children" 40 was "developed from a wish to record for posterity a unique episode in New Zealand's history - the arrival of the first refugee group in 1944 and its successful integration into New Zealand society" 41 . Written, published, and produced in 2004 by the refugees themselves and their descendants as part of the 60th anniversary of their arrival in 1944, the book commemorates their history with the purpose of dissemination. The preface reads that:

Their integration is a success story. It is the success of an unintentional experiment by New Zealand's wartime Government to accept refugees into a then very insular society. It is the success of the refugee children who made this country their home and positively contributed to it. It is a success made even more remarkable by the odds stacked against them - a childhood defined by wartime exile, horror and refuge. New Zealand's wartime Prime Minister Peter Fraser believed that Poland's loss was New Zealand's gain. His humanitarian gesture was instrumental in giving the children shelter in a society that was strange to them and not always welcoming. $[\ldots]$ It presents the subject from their own perspective, and is open to further research from archival materials and sources shown in this book ${ }^{42}$.

39 L. G. Calhoun, A. Cann, R. G. Tedeschi, The posttraumatic growth model: Sociocultural considerations, [in] T. Weiss and R. Berger (eds.), Posttraumatic Growth and Culturally Competent Practice: Lessons Learned from around the Globe, John Wiley \& Sons Inc. 2010, pp. 1-14.
40 S. Manterys and S. Zawada, op. cit.
41 Ibid., p. 4.
42 Ibid 
Tedeschi and Calhoun ${ }^{43}$ developed the posttraumatic growth inventory (PTGI; see Table 1), which identifies and evaluates the five factors of PTG. Thematic content analysis was done by coding the narratives and identifying words, groups of words, or sentences that fit the PTG items included in the PTGI. Because narratives were used, reports of positive aspects had to be analyzed in conjunction with other sections of the narratives to ascertain that changes occurred. In order to increase the reliability of the scoring, PTG items were identified by two raters trained in PTGI rating and scoring. Scores were finalized following discussions and once an agreement for the rating was reached. Fifty-one narratives from the book were analyzed for PTG. The final sample for this analysis was comprised of 29 narratives; excluded narratives contained no instances of PTG. The selected narratives were written by 29 people, 16 women and 13 men, who were at the Polish Children's Camp at Pahiatua in New Zealand for varying lengths of time between 1944 and 1949. The 29 narratives are a representative sample in terms of length of narrative and gender balance.

\section{Results}

Table 2 outlines the frequency of PTG factors overall and by gender. Overall and among women, the most frequent PTG factor in this sample was Relating to Others (Changes in Interpersonal Relationships). Among men, the most frequent PTG factor was New Possibilities. When combined with Personal Strength, the dimension of Changes in Perception of Self was most reported by men, at an equal frequency as women for Changes in Interpersonal Relationships.

\section{Changes in Interpersonal Relationships: Relating to others}

Although all 7 subfactors are represented in the narratives (see Table 1), the most frequent ones are subfactors 1 ("knowing that I can count on people in times of trouble), 2 ("a sense of closeness with others"), 6 (I learned a great

43 R. G. Tedeschi and L. G. Calhoun, op. cit., pp. 455-471. 
deal about how wonderful people are") and 7 (I accept needing others"). The context of these narratives was a relatively supportive, caring, and welcoming environment, both in Pahiatua and in New Zealand's broader society, according to the narratives in this particular text. As Janina K. expressed upon her arrival: "What we found was a heart-warming welcome. The beds were beautifully made and there were flowers in the rooms. I almost felt the love of the people who had prepared it all. I finally felt safe again" 44 . These sentiments are further expressed with relevance on a broader scale by Ryszard, who writes: "I could hardly believe that strangers could be so kind. I think this restored my faith in humanity" 45 .

Despite a relatively short stay in the safe space of Pahiatua, there appear to have been both immediate and long-lasting positive impacts in terms of changes in interpersonal relationships. The orphans appear to have created family-like bonds during this experience. This development is expressed by Janina S., who writes: "My stay in the camp was only for two years, as I left to attend college in Christchurch, but it was long enough for me to make lifelong family-type bonds among these special people in my life, to care for each other and to call ourselves "one of us"' 46 . With regards to a previous lack of family and close ties, Bogusław writes that:

For more than five years, we were without parents, and the camp life created a feeling of belonging and comradeship. This created the atmosphere of an extended family, which has been retained to varying degrees by most of us for the rest of our lives ${ }^{47}$.

These children were surrounded by a community of other Polish children and staff with similar migration experiences who were overall sources of social support, helping to instill a sense of belonging during their time at the camp following their traumatic experiences.

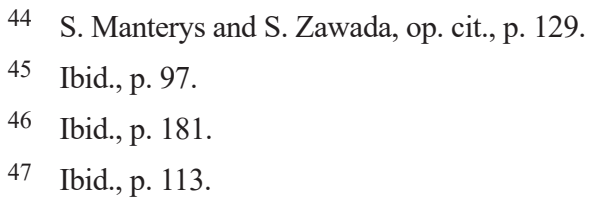




\section{Changes in perception of self: New possibilities and personal strength}

The PTG items of the Changes in Perception of Self dimension tended to cluster around subfactors 11 (New Possibilities: New opportunities are available which wouldn't have been otherwise"), 13 (Personal Strength: A feeling of self-reliance"), 14 (Personal Strength: "Knowing I can handle difficulties"), and 15 ("Personal Strength: "Being able to accept the way things work out").

New possibilities and a full life provided by time in Pahiatua, relative to the traumas that they had experienced, become evident when Bogusław states:

The usual routine life comprised church, meals, school classes, sports activities, general cleaning, hygiene and sleep. But during our free time on weekends a whole new range of opportunities became available. Exploring the camp's surroundings and the adjacent farms, forests and river was one of the most thrilling facets of camp life ${ }^{48}$.

These new possibilities went beyond the individual. Narratives also reflect the new possibilities that were made available for these refugee children as a group, and eventually their families. As Julian reflects: "New Zealand has provided me with the chance to bring up a family in a safe environment with many opportunities for them to become educated and realise their potential" 49 . Felicja furthers this idea: "Throughout my life, I encouraged my children to study and work hard. I believe that knowledge of the world and its people makes us more tolerant towards each other, and thus we become better citizens of this world" 50 . Moving from new possibilities towards personal strength, she then states: "I have had a good life and I am proud of what I have achieved." Accepting the way things turned out, Janina D. notes that: "Sixty years later at the age of 80 , I am leading a quiet life. I am grateful for my life - the good and the bad of it, the happy moments and the sad"51.

The context of Changes in Perception of Self appears to revolve around new possibilities in New Zealand in terms of work, education, activities, and

\footnotetext{
48 Ibid., p. 111.

49 Ibid., p. 154.

50 Ibid., p. 124.

51 Ibid., p. 90.
} 
potential for children and grandchildren, given that returning to a Poland under the Communist political system that was established after WWII - with affiliations to the Soviet Union and powers that had contributed to their traumas and orphan-status - was difficult both emotionally and logistically. The opportunity to create a new life and family (both biological and fraternal) where they could realize their potential, in New Zealand, was welcomed. Feelings of self-reliance, ability to handle difficulties, and accepting the way things work out may have been means to also move forward and take the opportunities that New Zealand provided, among those whose narratives reveal instances of PTG.

\section{Changes in philosophy of life: Spiritual change and appreciation of life}

In contrast to the previous dimensions, few examples of Changes in Philosophy of Life are explicitly documented here. They include subfactors 17 ("A better understanding of religious matters), 19 ("My priorities about what is important in life"), 20 ("An appreciation for the value of my life"), and 21 ("Appreciating each day"). Irena reflects that upon arrival in Pahiatua: "The joy of simply being alive filled my whole body. It was lovely to be, to live and to experience. Life was worth living" 52 . As a result of the experiences that he had, Stanislaw notes that even today: "I never take well-being and security for granted" 53 . Bogusław recalls that: "In [my brother and my] youth, we were exposed to hardship, pain, starvation, tragedy and sorrow. Despite this, I believe in God's presence and care over us throughout our ordeal." He continues: "I am therefore convinced that our survival and future blessings are God's way of compensating for having taken our mother so early in our lives" ${ }^{54}$. Similarly to the previous factors of change, arrival in New Zealand is regarded as positive and associated with a safe place that restored the will and ability to "live", manifesting for some as an increased appreciation of life.

\section{Overall context}

In part due to the uniqueness of government policies and welcome practices, New Zealanders and Polish caregivers appear to have provided

\footnotetext{
52 Ibid., p. 85.

53 Ibid., p. 150.

54 Ibid., p. 113.
} 
resources, care, and sincere acceptance to many of these child refugees who were recovering from the traumas of war and displacement. Doing so may have eased the children's adjustment to a foreign country while helping them to see the good in people. For these children, rather than migration to New Zealand having been construed as yet another negative experience, stressor, or setback, it appears, for many, to have been perceived as an opportunity that offered them a chance to build "a new life" following their traumatic experiences. The following narrative extract from Irena provides additional description regarding the context and experience of the youth who arrived in New Zealand in 1944.

When we arrived at the Polish Children's Camp in Pahiatua, lines of grey army barracks seemed to be everywhere. There was a beautiful freshness about it green patches of grass, some trees and a specific quality of happiness. Or, more correctly, an absence of threat and terror. There were New Zealand soldiers everywhere smiling at us and looking friendly. They were so different from the hostile, dangerous-looking adults who had been a large part of my experience in my young life.

Very soon after arriving, we were offered our first New Zealand meal. Miraculously, it seemed, all the 732 children were accommodated in several dining halls. Each child was handed a plate, and as we filed past an open server, colourful and delicious food was placed on it. I felt absolutely stunned to see so much food. This was because I remembered always being hungry, always looking for food. My reaction was to hide this food because I thought there might not be any more after this wonderful offering. But our Polish teachers circulated among us, encouraging us to eat and promising that tomorrow there would be more. [...]

The effect of eating regular meals began to change my body, I began to want to run and jump with my friends. We started to play games and we started to laugh. I don't think I had ever laughed before. They joy of simply being alive filled my whole body. It was lovely to be, to live and to experience. Life was worth living! [...]

As I look back on the planning and thought that the New Zealand authorities put into our reception, housing and programme of recovery for us at the camp, I am profo- 
undly thankful for the wonderful welcome and recovery programme that enabled us to begin a new life in this country. In Pahiatua, I came to appreciate the features of the country - its lush green landscape. Life in New Zealand for me had magic about it and a quality of excitement that I had never experienced before. [...]

We gradually made friends with many [New Zealand] girls who often invited us to stay with their families. This was a wonderful introduction to the warm-hearted and compassionate New Zealanders who took us in and treated us as their own children. They frequently treated us to new clothes, shoes and outings, as if we were their own. Meeting New Zealand families formed a valuable link to human goodness everywhere, and we formed lasting and enduring friendships. [...]

I frequently reflect on my life - the loss of my family, home and country in World War II, and our arrival in New Zealand as a bewildered group of war orphans. I also reflect on how fortunate I have been to have landed in this hospitable land. I salute the humanitarian concern of the New Zealand Government for having accepted us. I thank New Zealand for having given us shelter, food, education and the opportunity to build a new life ${ }^{55}$.

The children were largely in a safe and playful environment while their basic needs were satisfied. While it may not have been experienced in such a positive way for everyone (and further work is needed to fully understand the diversity of experiences), Irena's reflections strongly resonate with many of the narratives, regardless of whether or not instances of PTG were recorded.

\section{Discussion}

The analysis of individual narratives that represent a collective experience illuminates the role of the host country in the perception of this experience. It also highlights possible pathways to growth and transformation, namely contrasting PTG and gerotranscendence, given that these early experiences are recalled and communicated through a publication by the elderly people that they became.

55 Ibid., p. 85-88. 


\section{PTG and post migratory environments}

The most positive description that emerges across narratives is the impact of New Zealand as a receiving society that provided both a social context of welcome and well-being, along with important caregivers following various traumatic events. Unaccompanied refugee minors have been identified as a risk group. They are often missing the influence of caregivers who may help them be resilient and adaptive to stressful circumstances, and who are also integral to their development.

The narratives in this study clearly demonstrate that positive growth may occur despite the experience of a number of traumatic events. In fact, numerous positive growth factors, even a wide array of them, emerged in the narratives that were analyzed. Sociocultural contexts have a critical role in personal transformation ${ }^{56}$. Interactions with individuals in the immediate social environment relate to perceptions of growth. Evidence suggests that, across cultures, PTG correlates with social support in the forms of emotional comfort of growth modeling following adversity ${ }^{57}$. Self-disclosure and dialogue are some means by which PTG is facilitated among individuals affected by trauma, and therefore a responsive proximate social context should be considered as emotional support where role models may be provided ${ }^{58,59}$.

New traumatic experiences in the host country may reawaken past traumas, creating further adversity while diminishing potential positive adaptation $^{60}$. A challenge faced by migrant youth is the social, cultural, and linguistic differences that may exist between the place of origin and the new setting ${ }^{61}$. In terms of social acceptance and relations, both the Pahiatua Camp and the New Zealand society appear to have been reported as mostly positive experiences,

56 T. Weiss, op. cit., pp. 203-226.

57 T. Weiss and R. Berger, Posttraumatic growth around the globe: Research findings and practice implications, [in] T. Weiss and R. Berger (eds.), Posttraumatic Growth and Culturally Competent Practice: Lessons Learned from around the Globe, John Wiley \& Sons 2010, pp. 189-195.

58 L. G. Calhoun, A. Cann, R. G. Tedeschi, op. cit., pp. 1-14.

59 T. Weiss, op. cit., pp. 203-226.

60 R. S. Pynoos, A. M. Steinberg, and J. C. Piacentini, A developmental psychopathology model of childhood traumatic stress and intersection with anxiety disorders, "Biological Psychiatry", 46 (11): 1999, pp. 1542-1554.

61 M. Fazel, R. V. Reed, C. Panter-Brick, and A. Stein, op. cit., pp. 266-82. 
even when PTG was not explicitly recorded. These contexts appear to have promoted well-being in the post-migratory environment. Improved psychological functioning has been associated with high perceived peer support ${ }^{62}$, while perceived discrimination has been found in some studies to be an important predictor of depression and PTSD $^{63}$ but not in other studies ${ }^{64}$.

\section{Elderly people reflecting on childhood: Is this just gerotranscendence?}

The changes that present themselves in this study appear to be different from exclusively gerotrascendent processes, having occurred in childhood following the traumatic migratory experiences and settlement in New Zealand. The possibility exists that, in their old age, they are remembering their childhood experiences differently than they had actually occurred, possibly influenced by gerotranscendence. However, it is worth noting that, especially for those individuals whose narratives describe their lives up to the present, it appears as though some of these beneficial PTG changes had positive impacts in their youth on how they continued to live into old age, and in some cases for their children and grandchildren.

Sociocultural contexts and environments facilitate growth, being important for trauma survivors and the elderly alike. Narratives of positive transformation may occur when opportunities for reflection and contemplation in a supportive setting are present ${ }^{65}$. While age and gerotranscendence are theoretically connected, growth and positive changes as a result of adversity may occur across the lifespan. Although empirical findings are inconsistent, some interesting results have emerged regarding PTG and older age. The reporting of all three gerotranscendence dimensions increases with age, beginning in adulthood, at different rates based on gender and other factors ${ }^{66}$. For example,

62 L. Kovacev and R. Shute, Acculturation and social support in relation to psychosocial adjustment of adolescent refugees resettled in Australia, "International Journal of Behavioral Development", 28 (3): 2004, pp. 259-267.

63 B. H. Ellis, H. Z. MacDonald, A. K. Lincoln, and H. J. Cabral, Mental health of Somali adolescent refugees: The role of trauma, stress, and perceived discrimination, "Journal of consulting and clinical psychology", 76 (2): 2008, p. 184.

64 K. Liebkind, Acculturation and stress: Vietnamese refugees in Finland, "Journal of CrossCultural Psychology", 27 (2): 1996, pp. 161-180.

65 T. Weiss, op. cit., pp. 203-226.

66 L. Tornstam, op. cit. 
positive changes in philosophical/spiritual views were the highest rated changes among individuals in the 50-79 year age range in a study by Kurtz and colleagues ${ }^{67}$. Many of the Polish-New Zealanders were in the latter part of this age range when they wrote their narratives, yet narratives in this study had a minimal mention of positive changes in philosophical/spiritual views (which maps onto the Changes in Philosophy of Life PTG dimension). Weiss ${ }^{68}$ calls on additional empirical exploration of how PTG and gerotrascendence are related, noting that PTG as a possible precursor for gerotranscendence requires longitudinal work. This paper calls for continued exploration of diverse overlapping pathways to personal transformation.

\section{Limitations and future directions}

The 51 narratives that are included in the text "New Zealand's First Refugees: Pahiatua's Polish Children" were written on a volunteer and individual interest basis. Therefore, there is a degree of self-selection that took place, where those individuals interested in discussing and sharing their experiences in a public form shared their stories. More individuals may have participated or revealed different stories if there had been a greater degree of confidentiality provided in that text. Personal avoidance and a degree of censorship may be present. Greater diversity of narratives may lead to the emergence of different levels and types of PTG. Therefore, increasing the sample size by adding more narratives to the analysis would help offer insight into more diverse experiences and contexts. Also, as this study was limited to those children who were sent to New Zealand, an analysis of samples of children who had similar experiences in Siberia but were relocated to different refugee camps from their transit camps in Iran (especially to refugee camps in India, Lebanon, Mexico, and across Africa) could be done to identify similarities and differences among the subjects, thereby increasing the generalizability of results. Another consideration is the language of the narrative. Although many appear to have acquired a mastery of the English language, some who chose not to contribute may have

67 M. E. Kurtz, G. Wyatt, and J. C. Kurtz, Psychological and sexual well-being, philosophical/ spiritual views, and health habits of long-term cancer survivors, "Health Care for Women International", 16 (3): 1995, pp. 253-262.

68 T. Weiss, op. cit., pp. 203-226. 
done so because they felt that their English was not strong enough, which may be associated with other elements of their life experiences. Their narratives may have been written differently, with certain elements receiving more or less attention, if they were written in Polish rather than English.

Changes that occurred among the subjects could not always be accurately captured by the PTGI. This limitation may have been due to the wording of the items. For instance, an item under the Personal Strength factor includes "I discovered that I'm stronger than I thought I was" as a PTG factor. There were instances when PTG was implied, but the narrative does not provide enough information about their history and background to determine whether what they were indicating was a change or not. When uncertain, these instances were not included as examples of PTG. A future direction is to follow-up narratives with semi-structured interviews that allow liberty in how the interviews take place. Finally, the particular purpose of the book may have influenced the areas of emphasis that the individuals chose to discuss. By reviewing narratives that were written 60 years following the initial traumas of the migration experience, this analysis offers room to consider how memories may have changed over time, and how they are recalled during their elderly stage of life.

\section{Conclusion}

In 2020, we still have a lot to learn from the example of New Zealand's treatment of the Polish Children of Pahiatua. What was initially temporary refuge offered by New Zealand and Polish caregivers became a permanent home in which many of the survivors flourished. Many grew up to be happy, active citizens with an enduring love for their adopted country. These children went through several distressing experiences, including war, exile, loss of their family member(s), and migration. Childhood trauma can have lasting negative effects, yet individual narratives in this study demonstrated that rather than only experiencing overwhelming setbacks caused by their trauma experiences, there was a range of positive posttraumatic growth among some of the narrative contributors. The most frequent examples of PTG were Relating to Others, Personal Strength, and New Possibilities. The kindness and care of many of their caregivers and New Zealanders appears to have been part of their growth 
process, as was their access to resources that may otherwise not have been available to children during and following the wartime period. Working with now elderly survivors of childhood trauma, we need to work to identify what helped them survive, grow, and rebuild their lives while being mindful of possible gerotranscendence. Noteworthy research endeavours include a focus on the conditions that encourage growth following trauma, and personal transformations that emerge in narratives.

While there is a uniqueness to their story and experience, there is also an important common and relevant thread to be understood. Childhood migration is not uncommon today. Increasing attention has been placed on the treatment of children who are asylum seekers, refugees, and immigrants during their various stages of migration. There appears to be a period following trauma when stress may be compounded or when growth may be facilitated. This growth and these positive memories may prove to offer healing and support across the lifespan. 


\section{Table 1}

Posttraumatic Growth Inventory

Factors of Posttraumatic Growth

A. Relating to Others

1. Knowing that I can count on people in times of trouble.

2. A sense of closeness with others.

3. A willingness to express my emotions.

4. Having compassion for others.

5. Putting effort into my relationships.

6. I learned a great deal about how wonderful people are.

7. I accepted needing others.

B. New Possibilities

8. I developed new interests.

9. I established a new path in life.

10. I'm able to do better things with my life.

11. New opportunities are available which wouldn't have been otherwise.

12. I'm more likely to try to change things which need changing.

C. Personal Strength

13. A feeling of self-reliance.

14. Knowing I can handle difficulties.

15. Being able to accept the way things work out.

16. I discovered that I'm stronger than I thought I was.

D. Spiritual Change

17. A better understanding of spiritual matters.

18. I have stronger religious faith.

E. Appreciation of Life

19. My priorities about what is important in life.

20. An appreciation for the value of my life.

21. Appreciating each day. 


\section{Table 2}

Factors of PTG Reported by Women, Men, and Total Combined

\begin{tabular}{|l|c|c|c|}
\hline Factors & Women & Men & Total \\
\hline Relating to Others & 13 & 6 & 19 \\
\hline New Possibilities & 4 & 8 & 12 \\
\hline Personal Strength & 7 & 5 & 12 \\
\hline Spiritual Change & 0 & 2 & 2 \\
\hline Appreciation of Life & 1 & 4 & 5 \\
\hline
\end{tabular}

\section{References}

Ager, A., Stark, L., Akesson, B., \& Boothby, N. (2010). Defining Best Practice in Care and Protection of Children in Crisis-Affected Settings: A Delphi Study. Child Development, 81(4), 1271-1286.

Aldwin, C., \& Levenson, M. (2004). Posttraumatic growth: A developmental perspective, Psychological Inquiry, 15, 19-22.

Antonovsky, A. (1979). Health, Stress, and Coping, Jossey-Bass, San Francisco.

Antosiewicz, M., \& Kubalska-Sulkiewicz, K. (2004). Polska Szkoła Na Tułaczych Szlakach; Polish Schooling in War-time Exile, Warsaw FAFT.

Calhoun, L. G., Cann, A., \& Tedeschi, R. G. (2010). The posttraumatic growth model: Sociocultural considerations, [in] T. Weiss \& R. Berger (eds.), Posttraumatic Growth and Culturally Competent Practice: Lessons Learned from around the Globe (pp. 1-14). John Wiley \& Sons Inc.

Calhoun, L. G., \& Tedeschi, R. G. (1998). Posttraumatic growth: Future directions. In R. G. Tedeschi, C. L. Park, \& L. G. Calhoun (Eds.), Posttraumatic growth: Positive changes in the aftermath of crisis (pp. 215-238). Mahwah, NJ: Lawrence Erlbaum Associates.

Calhoun, L. G. \& Tedeschi, R. G. (1999). Facilitating Posttraumatic Growth: A Clinician's Guide, London: Erlbaum. 
Cryder, C. H., Kilmer, R. P., Tedeschi, R. G., \& Calhoun, L. G. (2006). An exploratory study of posttraumatic growth in children following a natural disaster, American Journal of Orthopsychiatry, 76 (1), 65-69.

Davies, N. (2015). Trail of Hope: The Anders Army, an Odyssey Across Three Continents. Oxford: Osprey Publishing.

Ellis, B. H., MacDonald, H. Z., Lincoln, A. K., \& Cabral, H. J. (2008). Mental health of Somali adolescent refugees: The role of trauma, stress, and perceived discrimination. Journal of consulting and clinical psychology, 76(2), 184.

Fazel, M., Reed, R. V., Panter-Brick, C., \& Stein, A. (2012). Mental health of displaced and refugee children resettled in high-income countries: Risk and protective factors. Lancet, 379, 266-82.

Frankl, V. E. (1984). Man's Search for Meaning (revised and updated). New York: Square Press/Pocket Books.

Giberovitch, M. (2014). Recovering from Genocidal Trauma: An Information and Practice Guide for Working with Holocaust Survivors. Toronto: University of Toronto Press.

Jolluck, K. (2002). Exile and Identity: Polish Women in the Soviet Union during World War II. Pittsburg: University of Pittsburg Press.

Kovacev, L., \& Shute, R. (2004). Acculturation and social support in relation to psychosocial adjustment of adolescent refugees resettled in Australia. International Journal of Behavioral Development, 28(3), 259-267.

Krolikowski, L. (2001). Stolen Childhood: A Saga of Polish War Children. Buffalo: Author's Choice Press.

Kurtz, M. E., Wyatt, G., \& Kurtz, J. C. (1995). Psychological and sexual well-being, philosophical/spiritual views, and health habits of long-term cancer survivors. Health Care for Women International, 16(3), 253-262.

Lazarus, R. S., \& Folkman, S. (1987). Transactional theory and research on emotions and coping. European Journal of Personality, 1(3), 141-169.

Liebkind, K. (1996). Acculturation and stress Vietnamese refugees in Finland. Journal of Cross-Cultural Psychology, 27(2), 161-180.

Manterys, S. \& Zawada, S. (Eds.). (2004). New Zealand's First Refugees: Pahiatua's Polish Children. Wellington: Polish Children's Reunion Committee.

Masten, A. S., Best, K. M., \& Garmezy, N. (1990). Resilience and development: Contributions from the study of children who overcome adversity. Development and Psychopathology, 2(4), 425-444. 
Peddle, N. (2007). Assessing trauma impact, recovery, and resiliency in refugees of war. Journal of Aggression, Maltreatment \& Trauma, 14(1-2), 185-204.

Pynoos, R. S., Steinberg, A. M., \& Piacentini, J. C. (1999). A developmental psychopathology model of childhood traumatic stress and intersection with anxiety disorders. Biological Psychiatry, 46(11), 1542-1554.

Robinson, S., Rapaport-Bar-Sever, M., \& Rapaport, J. (1994). The present state of people who survived the Holocaust as children. Acta Psychiatrica Scandinavica, 89(4), 242-245.

Sigal, J. J., \& Weinfeld, M. (2001). Do children cope better than adults with potentially traumatic stress? A 40-year follow-up of Holocaust survivors. Psychiatry, 64(1), 69-80.

Suedfeld, P., Soriano, E., McMurtry, D. L., Paterson, H., Weiszbeck, T. L., \& Krell, R. (2005). Erikson's "components of a healthy personality" among Holocaust survivors immediately and 40 years after the war. International Journal of Aging and Human Development, 60(3), 229-248.

Tedeschi, R. G., \& Calhoun, L. G. (1996). The posttraumatic growth inventory: Measuring the positive legacy of trauma. Journal of Traumatic Stress, 9(3), 455471.

Tedeschi, R. G., \& Calhoun, L G. (2004). Posttraumatic growth: Conceptual foundations and empirical evidence. Psychological Inquiry, 15(1), 1-18.

Tornstam, L. (2005). Gerotranscendence: A Developmental Theory of Positive Aging. Springer Publishing Company.

Weiss, T., \& Berger, R. (2010). Posttraumatic growth around the globe: Research findings and practice implications, [in] T. Weiss \& R. Berger (eds.), Posttraumatic Growth and Culturally Competent Practice: Lessons Learned from around the Globe (pp. 189-195). John Wiley \& Sons.

Weiss, T. (2014). Personal transformation: Posttraumatic growth and gerotranscendence. Journal of Humanistic Psychology, 54(2), 203-226. 